\title{
The Netherlands Sports Cardiology Map: a step towards sports cardiology network medicine for patient and athlete care
}

\author{
J. C. van Hattum · S. M. Verwijs · R. Rienks · N. R. Bijsterveld • S. T. de Vries · Y. M. Pinto · A. A. M. Wilde • \\ H. T. Jørstad
}

Accepted: 3 December 2020 / Published online: 23 December 2020

(c) The Author(s) 2020

\begin{abstract}
Sports cardiology is a rapidly evolving subspecialty of cardiology, with a growing demand for expertise. To improve patient care, clinicians, patients, and athletes (recreational to elite) should be able to easily identify specialised care pathways, expertise centres and clinicians with sports cardiology expertise. To this purpose, several international societies and organisations recommend establishing a local and national sports cardiology infrastructure. We therefore aimed to establish The Netherlands Sports Cardiology Map. We conducted a web-based survey, which was published on the Netherlands Society of Cardiology home page (2019-2020) and in which each cardiology department or clinic was asked to provide information on sports cardiology expertise and the current infrastructure. Of the 46 respondent centres, $28(61 \%)$ reported that they had expertise in sports cardiology, of which 22 (79\%) had specific expertise in one or more specific types of sports. Integrated multidisciplinary meetings were reported by $43 \%$ of the centres $(n=12 / 28)$. Only two centres reported ongoing research projects that had been approved by an institutional review board. The Netherlands Sports
\end{abstract}

J. C. van Hattum $(\bowtie) \cdot$ S. M. Verwijs · Y. M. Pinto ·

A. A. M. Wilde $\cdot$ H. T. Jørstad

Department of Cardiology, Heart Center, Amsterdam UMC,

University of Amsterdam, Amsterdam Cardiovascular

Sciences, Amsterdam, The Netherlands

j.c.vanhattum@amsterdamumc.nl

R. Rienks

CardioExpert, Amsterdam, The Netherlands

N. R. Bijsterveld

Department of Cardiology, Flevo Hospital, Almere, The Netherlands

\section{S. T. de Vries}

Department of Cardiology, Tjongerschans Hospital,

Heerenveen, The Netherlands
Cardiology Map is an important step towards improving the existing infrastructure and developing network medicine for sports cardiology.

Keywords Sports cardiology · Map · Overview · Network · Infrastructure

Sports cardiology is a rapidly evolving subspecialty of cardiology, with a growing demand for expertise. According to the Dutch Olympic Committee*Dutch Sports Federation (NOC*NSF), 65\% of the Dutch aged 5-80 years participate in sports at least four times per month. In addition, there are 5 million athletes who are associated with sports federations and 800 elite athletes who are registered as (potential) Olympic games participants.

The challenge for sports cardiology healthcare professionals is to maximise safety in sports, through cardiovascular screenings, differentiating cardiac remodelling from pathology, and clinical evaluation and management of symptomatic athletes or athletes with cardiovascular disease, ranging from amateur to elite levels. To this purpose, the American College of Cardiology [1] and the European Society of Cardiology (ESC) [2] have both published (proposed) sports cardiology core curriculums; they also update consensus documents on a regular basis. Sports medicine healthcare professionals have further emphasised the need for multidisciplinary networks, with the American Medical Society for Sports Medicine recommending the establishment of a dedicated infrastructure for local collaborations and partnerships between sports physicians and sports cardiologists. This American society also recommends that regional expert centres are established to assist in electrocardiogram interpretation and evaluation of athletes with suspected or known cardiovascular disorders [3]. In line with 
this, the Sports Cardiology Section of the European Association of Preventive Cardiology has stated that offering uniform protocolised care for risk stratification and management is an important challenge in the management of athletes with cardiac disease [4-9]. In addition to the establishment of regional expert centres, this requires national and international educational events to update and improve sports cardiologists' skills in and knowledge of the continuously developing field of athlete care [2].

To address these challenges, the Sports Cardiology Section of the Netherlands Society of Cardiology (NVVC) was founded, which aims to promote education, to contribute to national protocols and consen- sus statements, and to stimulate research in the broad field of sports cardiology. As a first step in establishing further infrastructure and expert centres, regional centres and expertise need to be identified. We therefore aimed to establish The Netherlands Sports Cardiology Map to enable clinicians, patients, and athletes (recreational to elite) to easily identify expertise centres and clinicians with sports cardiology expertise.

\section{Survey}

We conducted a web-based survey, which was published on the NVVC home page (2019-2020). In this survey, each cardiology department or clinic was
Fig. 1 The Netherlands Sports Cardiology Map, consisting of 28 centres with expertise in sports cardiology (1 located in Belgium). Integrated multidisciplinary meetings are held at Amsterdam University Medical Centre (UMC), Cardiology Centre the Netherlands (CCN)Amsterdam UMC, Flevo Hospital, Haaglanden Medical Centre (HMC), Isala Hospital, Máxima Medical Centre (MC), Meander MC, Northwest Clinics (NWZ) Alkmaar, Onze Lieve Vrouw Gasthuis (OLVG) West, Saxenburgh Medical Centre (SXB) Hardenberg, Wilhelmina Hospital Assen (WHA) and Hospital Gelderse Vallei (ZGV). Amsterdam UMC, Máxima MC, Meander MC and OLVG West collaborate with Dutch Olympic Committee*Dutch Sports Federation ( $\mathrm{NOC}^{\star} \mathrm{NSF}$ ), as cardiology High-Performance Partners of TeamNL. Research projects approved by institutional review board (IRB) are carried out at Amsterdam UMC and Máxima MC. ADRZ Admiraal de Ruyter Hospital, AMC Amsterdam Medical Centre, CWZ Canisius-Wilhelmina Hospital, MST Medical Spectrum Twente, RKZ Red Cross Hospital, SKB Regional Hospital Queen Beatrix, VUmc Free University medical centre

\section{THE NETHERLANDS SPORTS CARDIOLOGY MAP}

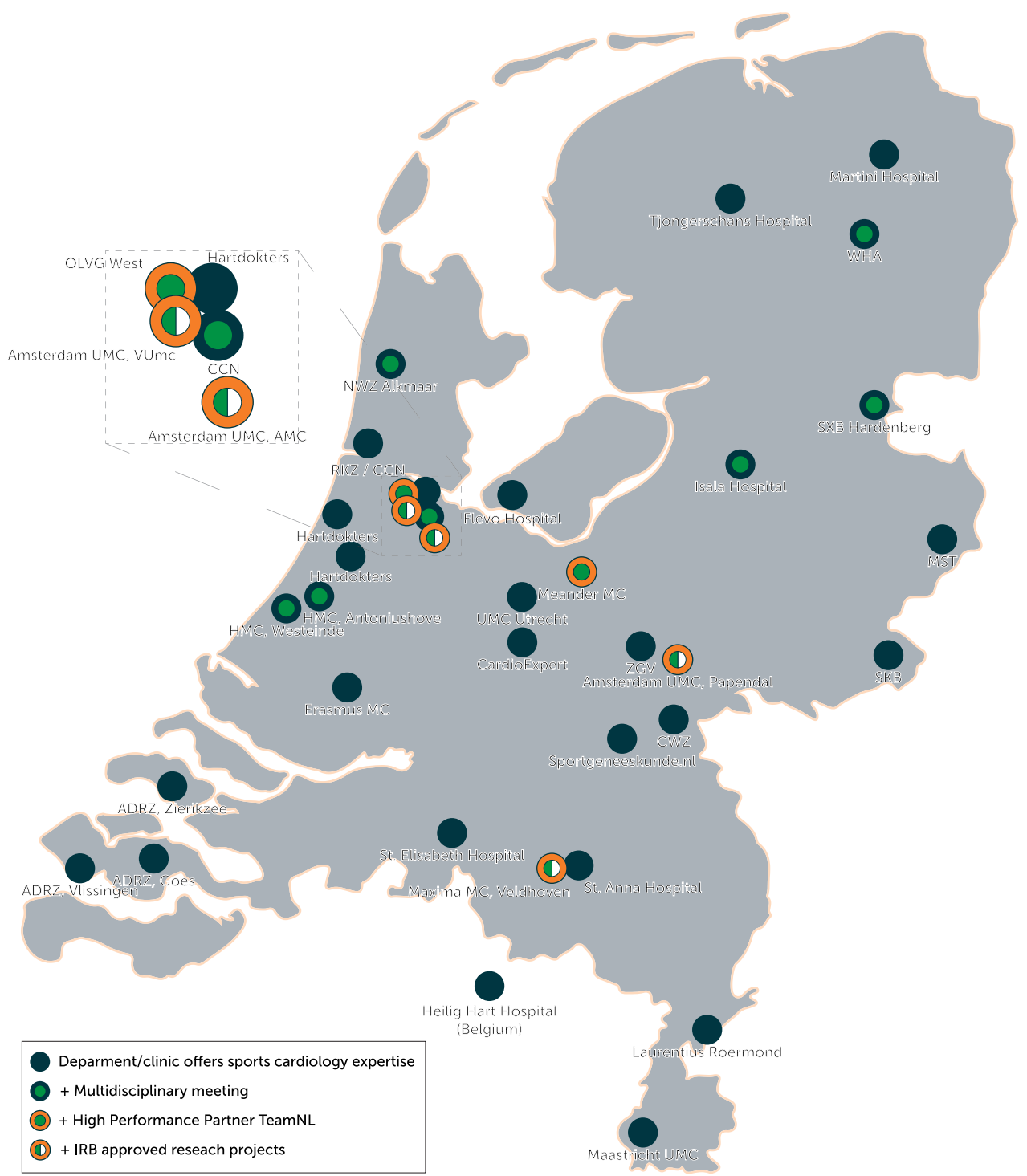


Table 1 Synopsis of The Netherlands Sports Cardiology Map

\begin{tabular}{|c|c|c|c|c|c|c|c|}
\hline $\begin{array}{l}\text { Cardiology de- } \\
\text { partment/clinic }\end{array}$ & $\begin{array}{l}\text { High- } \\
\text { Perfor- } \\
\text { mance } \\
\text { Partner } \\
\text { TeamNL }\end{array}$ & City & $\begin{array}{l}\text { Primary con- } \\
\text { tact (cardiolo- } \\
\text { gist) }\end{array}$ & Specific expertise & $\begin{array}{l}\text { Collaboration } \\
\text { with sports } \\
\text { club or sports } \\
\text { federation }\end{array}$ & Multidisciplinary meeting & $\begin{array}{l}\text { IRB- } \\
\text { approved } \\
\text { research } \\
\text { projects }\end{array}$ \\
\hline $\begin{array}{l}\text { Admiraal de } \\
\text { Ruyter Hospital }\end{array}$ & - & $\begin{array}{l}\text { Goes; Vlissin- } \\
\text { gen; Zierikzee }\end{array}$ & $\begin{array}{l}\text { M.H.H. de } \\
\text { Vaan, MD, PhD }\end{array}$ & Diving & - & - & - \\
\hline Amsterdam UMC & Yes & $\begin{array}{l}\text { Amsterdam } \\
\text { (AMC and } \\
\text { VUmc); Papen- } \\
\text { dal }\end{array}$ & $\begin{array}{l}\text { H.T. Jorstad, } \\
\text { MD, PhD }\end{array}$ & $\begin{array}{l}\text { Elite sports; soccer; tennis; } \\
\text { cycling; rowing; endurance } \\
\text { sports; field hockey; water } \\
\text { polo }\end{array}$ & $\begin{array}{l}\text { AFC Ajax; } \\
\text { KNLTB; KNVW; } \\
\text { NOC*NSF }\end{array}$ & $\begin{array}{l}\text { Cardiologists, sports physi- } \\
\text { cians, cardiac EPs, genetics, } \\
\text { radiologists, pulmonologist, } \\
\text { paediatric cardiologists }\end{array}$ & Yes \\
\hline $\begin{array}{l}\text { Canisius- } \\
\text { Wilhelmina } \\
\text { Hospital }\end{array}$ & - & Nijmegen & $\begin{array}{l}\text { E.S. Zegers, } \\
\text { MD, PhD }\end{array}$ & Soccer & N.E.C. & - & - \\
\hline CardioExpert & - & Bunnik & $\begin{array}{l}\text { R. Rienks, MD, } \\
\text { PhD }\end{array}$ & $\begin{array}{l}\text { Diving; elite sports; soccer; } \\
\text { high altitude sports; flying; } \\
\text { extreme sports }\end{array}$ & KNVB & - & - \\
\hline $\begin{array}{l}\text { CCN, Amsterdam } \\
\text { UMC, location } \\
\text { AMC }\end{array}$ & - & Amsterdam & $\begin{array}{l}\text { M. Speleman, } \\
\text { MD, PhD }\end{array}$ & - & - & At Amsterdam UMC & - \\
\hline $\begin{array}{l}\text { Erasmus Medical } \\
\text { Centre }\end{array}$ & - & Rotterdam & $\begin{array}{l}\text { T.W. Galema, } \\
\text { MD, PhD }\end{array}$ & Soccer & Feyenoord & - & - \\
\hline Flevo Hospital & - & Almere & $\begin{array}{l}\text { N. Bijsterveld, } \\
\text { MD, PhD }\end{array}$ & - & - & At Amsterdam UMC & - \\
\hline $\begin{array}{l}\text { Haaglanden } \\
\text { Medical Centre }\end{array}$ & - & $\begin{array}{l}\text { Leidschendam } \\
\text { (Antoniushove) } \\
\text { Den Haag } \\
\text { (Westeinde) }\end{array}$ & $\begin{array}{l}\text { B.J. Sorgdrager, } \\
\text { MD, PhD }\end{array}$ & $\begin{array}{l}\text { Soccer; cycling; en- } \\
\text { durances sports; field } \\
\text { hockey; diving }\end{array}$ & AD0; KNVB & $\begin{array}{l}\text { Cardiologists, sports physi- } \\
\text { cians, pulmonologists }\end{array}$ & - \\
\hline Hartdokters & - & $\begin{array}{l}\text { Amsterdam } \\
\text { KG/W; Leiden; } \\
\text { Noordwijk }\end{array}$ & $\begin{array}{l}\text { J.J. Regieli, } \\
\text { MD, PhD }\end{array}$ & $\begin{array}{l}\text { Diving; altitude sports } \\
\text {-cycling; running }\end{array}$ & - & - & - \\
\hline $\begin{array}{l}\text { Heilig Hart Hospi- } \\
\text { tal } \\
\text { (Sportgenees- } \\
\text { kunde.nl) }\end{array}$ & - & $\begin{array}{l}\text { Mol, Belgium; } \\
\text { Oss }\end{array}$ & $\begin{array}{l}\text { J.P.M. van } \\
\text { Asseldonk, MD, } \\
\text { PhD }\end{array}$ & Soccer & TOP Oss & - & - \\
\hline $\begin{array}{l}\text { Hospital Gelderse } \\
\text { Vallei }\end{array}$ & - & Ede & $\begin{array}{l}\text { M.J. van der } \\
\text { Veen, MD, PhD }\end{array}$ & - & Sports Valley & At Amsterdam UMC & - \\
\hline Isala Hospital & - & Zwolle & $\begin{array}{l}\text { J.R. Timmer, } \\
\text { MD, PhD }\end{array}$ & Speed skating & $\begin{array}{l}\text { PEC Zwolle; } \\
\text { Lotto Jumbo }\end{array}$ & $\begin{array}{l}\text { Cardiologists and sports } \\
\text { physicians }\end{array}$ & - \\
\hline $\begin{array}{l}\text { Laurentius Hos- } \\
\text { pital Roermond }\end{array}$ & - & Roermond & $\begin{array}{l}\text { R. van der } \\
\text { Borgh, MD }\end{array}$ & $\begin{array}{l}\text { Endurance sports; altitude } \\
\text { sports }\end{array}$ & $\begin{array}{l}\text { Sunweb cycling } \\
\text { team }\end{array}$ & - & - \\
\hline Maastricht UMC & - & Maastricht & $\begin{array}{l}\text { C. Knackstedt, } \\
\text { MD, PhD }\end{array}$ & - & $\begin{array}{l}\text { Boels-Dolmans } \\
\text { Cycling }\end{array}$ & - & - \\
\hline $\begin{array}{l}\text { Martini Hospital } \\
\text { Groningen }\end{array}$ & - & Groningen & $\begin{array}{l}\text { J.L. Posma, } \\
\text { MD, PhD }\end{array}$ & Soccer; basketball & $\begin{array}{l}\text { FC Groningen; } \\
\text { Donar basketball }\end{array}$ & - & - \\
\hline $\begin{array}{l}\text { Máxima Medical } \\
\text { Centre }\end{array}$ & Yes & Veldhoven & $\begin{array}{l}\text { J. Hoogsteen, } \\
\text { MD, PhD }\end{array}$ & $\begin{array}{l}\text { Elite sports; speed skating; } \\
\text { cycling; soccer }\end{array}$ & $\begin{array}{l}\text { PSV; Jum- } \\
\text { bo-Visma; CSC; } \\
\text { NOC*NSF }\end{array}$ & $\begin{array}{l}\text { Cardiologists and sports } \\
\text { physicians }\end{array}$ & Yes \\
\hline $\begin{array}{l}\text { Meander Medical } \\
\text { Centre }\end{array}$ & Yes & Amersfoort & $\begin{array}{l}\text { P.J. Senden, } \\
\text { MD, PhD }\end{array}$ & Elite sports; soccer; cycling & $\begin{array}{l}\text { FC Utrecht; } \\
\text { NOC*NSF }\end{array}$ & $\begin{array}{l}\text { Cardiologists, sports physi- } \\
\text { cians, pulmonologists, radiolo- } \\
\text { gists }\end{array}$ & - \\
\hline $\begin{array}{l}\text { Medical Spec- } \\
\text { trum Twente }\end{array}$ & - & Enschede & $\begin{array}{l}\text { M.F. Scholten, } \\
\text { MD, PhD }\end{array}$ & - & - & - & - \\
\hline $\begin{array}{l}\text { Noordwest Clin- } \\
\text { ics }\end{array}$ & - & Alkmaar & $\begin{array}{l}\text { G.P. Kimman, } \\
\text { MD, PhD }\end{array}$ & Soccer & AZ & $\begin{array}{l}\text { Cardiologists and sports } \\
\text { physicians }\end{array}$ & - \\
\hline oLVG West & Yes & Amsterdam & $\begin{array}{l}\text { A.R. Willems, } \\
\text { MD, PhD }\end{array}$ & Elite sports & NOC ${ }^{*}$ NSF & At Amsterdam UMC & - \\
\hline
\end{tabular}


Table 1 (Continued)

\begin{tabular}{|c|c|c|c|c|c|c|c|}
\hline $\begin{array}{l}\text { Cardiology de- } \\
\text { partment/clinic }\end{array}$ & $\begin{array}{l}\text { High- } \\
\text { Perfor- } \\
\text { mance } \\
\text { Partner } \\
\text { TeamNL }\end{array}$ & City & $\begin{array}{l}\text { Primary con- } \\
\text { tact (cardiolo- } \\
\text { gist) }\end{array}$ & Specific expertise & $\begin{array}{l}\text { Collaboration } \\
\text { with sports } \\
\text { club or sports } \\
\text { federation }\end{array}$ & Multidisciplinary meeting & $\begin{array}{l}\text { IRB- } \\
\text { approved } \\
\text { research } \\
\text { projects }\end{array}$ \\
\hline $\begin{array}{l}\text { Regional Hospital } \\
\text { Queen Beatrix }\end{array}$ & - & Winterswijk & $\begin{array}{l}\text { P. Sijbring, MD, } \\
\text { PhD }\end{array}$ & Soccer & De Graafschap & - & - \\
\hline $\begin{array}{l}\text { RKZ } \\
\text { Beverwijk/CCN }\end{array}$ & - & $\begin{array}{l}\text { Beverwijk; } \\
\text { IJmond }\end{array}$ & $\begin{array}{l}\text { M.A.C. Koole, } \\
\text { MD }\end{array}$ & $\begin{array}{l}\text { Cycling; speed skating; } \\
\text { running; rowing; strength } \\
\text { training }\end{array}$ & Telstar & - & - \\
\hline St. Anna Hospital & - & Geldrop & $\begin{array}{l}\text { J.H.P. Janssen, } \\
\text { MD, PhD }\end{array}$ & Swimming; soccer & $\begin{array}{l}\text { PSV; VW; PSV } \\
\text { swimming; } \\
\text { Helmond Sport }\end{array}$ & - & - \\
\hline $\begin{array}{l}\text { St. Elisabeth } \\
\text { Hospital }\end{array}$ & - & Tilburg & $\begin{array}{l}\text { A.C.B. Pronk, } \\
\text { MD, PhD }\end{array}$ & Soccer & Willem II & - & - \\
\hline SXB Hardenberg & - & Hardenberg & $\begin{array}{l}\text { J.T. Drost, MD, } \\
\text { PhD }\end{array}$ & Endurance sports & $\begin{array}{l}\text { PEC Zwolle } \\
\text { Woman }\end{array}$ & $\begin{array}{l}\text { Cardiologists, sports physi- } \\
\text { cians, rehabilitation physi- } \\
\text { cians }\end{array}$ & - \\
\hline $\begin{array}{l}\text { Tjongerschans } \\
\text { Hospital }\end{array}$ & - & Heerenveen & $\begin{array}{l}\text { S.T. de Vries, } \\
\text { MD, PhD }\end{array}$ & $\begin{array}{l}\text { Speed skating; marathon; } \\
\text { triathlon; soccer }\end{array}$ & SC Heerenveen & - & - \\
\hline $\begin{array}{l}\text { UMC Utrecht, } \\
\text { Central Military } \\
\text { Hospital }\end{array}$ & - & Utrecht & $\begin{array}{l}\text { Prof. P.A. F. Do- } \\
\text { evedans, MD, } \\
\text { PhD }\end{array}$ & Soccer & FC Utrecht & - & - \\
\hline $\begin{array}{l}\text { Wilhelmina } \\
\text { Hospital Assen }\end{array}$ & - & Assen & $\begin{array}{l}\text { J.K. Jongman, } \\
\text { MD }\end{array}$ & - & - & $\begin{array}{l}\text { Cardiologists and sports } \\
\text { physicians }\end{array}$ & - \\
\hline
\end{tabular}

asked to provide information on sports cardiology expertise and the current infrastructure. We collected data on specific fields of expertise, specific fields of interest and expertise in particular sports. Also, data on the presence of (formalised) collaborations with professional sports clubs or federations, organised (multidisciplinary) sports cardiology meetings or panels (with details of participating disciplines), and ongoing studies approved by an institutional review board (IRB) were collected. Finally, we collected data on (formalised) collaborations with sports physicians, sports federation physicians and NOC*NSF. All data were self-reported; no quality criteria were applied when listing centres of expertise. Based on the collected data, we designed a map with centres of expertise and a list of specific features per centre.

In total, 46 centres (52\% of NVVC-registered cardiology departments or clinics) responded to the survey (1 centre located in Belgium). Twenty-eight centres (61\%) reported that they had a specific outpatient clinic for sports cardiology or had one or more cardiologists with expertise in sports cardiology (Fig. 1). The majority $(79 \%, n=22 / 28)$ reported sports specific expertise, predominantly in soccer $(71 \%)$, endurance sports/long distance running (32\%), cycling (27\%), speed skating (18\%) or diving (18\%). Collaborations with clubs or sports federations were reported by $79 \%$ of the centres $(n=22 / 28)$ and $14 \%(n=4 / 28)$ reported a cardiology collaboration with NOC*NSF as so-called 'High-Performance Partner' of TeamNL; TeamNL comprises athletes who have been selected to represent the Netherlands internationally. Integrated multidisciplinary meetings on a regular basis were reported by $43 \%(n=12 / 28)$, mostly attended by cardiologists and sports physicians only (58\%) and less frequently by pulmonologists, radiologists or rehabilitation physicians. A small number of collaborating centres $(n=5 / 12)$ reported attending extensive meetings organised by the Amsterdam University Medical Centre (UMC), including participation of additional disciplines (genetics, molecular cardiology, paediatric cardiology, electrophysiology, cardiac imaging, nuclear medicine). Only two centres (Máxima Medical Centre and Amsterdam UMC) reported ongoing research projects that had been approved by an IRB (Tab. 1).

The Netherlands Sports Cardiology Map, including the expertise listing, represents an important step towards a sports cardiology infrastructure and network medicine. According to this first survey, about a quarter of the NVVC-registered departments or clinics have expertise in sports cardiology. This suggests a high level of interest in a relatively young and developing subspecialty of cardiology. Furthermore, predominantly sports with a low-static/high-dynamic component[10] are fields of expertise; soccer was reported by the majority $(71 \%)$. This potentially reflects the demand for such expertise from clubs and sports organisations and a relatively large number of departments and clinics with interest in providing such expertise. However, numerous popular sports are currently not well represented in the expertise listing, 
such as weightlifting, skiing, motor sports and boxing.

This first sports cardiology survey in the Netherlands was designed to make an inventory of existing initiatives, without applying any quality criteria. While a limited number of countries have established career tracks for sports cardiologists, there are initiatives aimed at addressing this matter. Sports cardiology senior residencies are currently offered in two medical centres in the Netherlands (Máxima Medical Centre and Amsterdam UMC). The NVVC and ESC are both in the process of evaluating whether fellowships in sports cardiology or preventive cardiology (with sports as an integral part) should be developed. Furthermore, the ESC offers an application process for European accreditation as an expert centre in sports cardiology. Finally, the 'High-Performance Partner' status, which has been offered to four cardiology departments in the Netherlands, is preceded by an internal evaluation performed by the medical staff of NOC*NSF. As the abovementioned initiatives are further developed, cardiology departments/clinics or individual cardiologists will gradually have access to different opportunities to distinguish themselves with expertise, collaborations or accreditations.

Our survey demonstrates that network medicine in sports cardiology is in development. One third of the respondent centres have already integrated multidisciplinary meetings on a regular basis, which are mostly attended by sports cardiologists and sports physicians. A number of these centres contribute to one larger multidisciplinary meeting. With the current level of interest in sports cardiology and clinical collaborations, further development of such meetings and panels seems warranted.

With only two centres reporting IRB-approved research projects, there is clearly a need for stimulation of sports cardiology research and research collaborations in the Netherlands. While this is almost certainly an underrepresentation of the real number of sports cardiology research projects, it is of concern that within the described clinical network, only a fraction of the centres are actively involved in sports cardiology research. Initiatives to integrate sports cardiology into collaborations with other disciplines, such as sports medicine, human movement science and public health, offer opportunities to advance sports cardiology research tracks. Furthermore, policy makers involved in writing knowledge agendas should urgently be made aware of the unmet needs of athletes, patients, and healthcare professionals in sports cardiology.

\section{Limitations}

With regard to our survey and its results, a number of limitations should be taken into account. First, we performed a web-based survey based on self-reporting that was accessible to all NVVC-registered cardi- ologists. Therefore, all drawbacks pertaining to selfreporting apply.

Second, no quality criteria were applied to our map or listing. Future developments for accreditation or quality standards could hypothetically include levels of expertise for individuals or centres. For example, a level-1 accreditation could entail attending a minimum of one national course (offered by the Dutch Cardiovascular Educational Institute) and one international course or congress in sports cardiology (offered by an organisation for preventive/sports cardiology, f.e. the European Association of Preventive Cardiology). In addition, a level-2 accreditation would require a certain patient volume, additional expertise and partial accreditation according to national and European core curricula in preventive cardiology. A level-3 accreditation could, for example, entail a full accreditation in preventive cardiology, an established multidisciplinary collaboration and active research programmes.

Third, the current sports cardiology map is designed as a static illustration; it is preferable to adopt a live platform with regular updates and links to the different centres of expertise.

Finally, our survey was not designed to collect data on educational tracks in sports cardiology. While integration of such educational tracks would be of interest to most sports cardiology professionals, this was outside the scope of the current survey.

\section{Conclusion}

The Netherlands Sports Cardiology Map (Fig. 1) is an important step towards effective network medicine for patients, clinicians and researchers. Such a map and the accompanying listing of expertise assist individuals in easily identifying current care pathways, finding collaborators to improve educational tracks and establishing research collaborations.

Funding H.T. Jørstad has received funding from the Amsterdam Movement Sciences (P1A210AMC2018) and the Dutch Olympic Committee*Dutch Sports Federation.

Conflict of interest J.C. van Hattum, S.M. Verwijs, R. Rienks, N.R. Bijsterveld, S.T. de Vries, Y.M. Pinto, A.A.M. Wilde and H.T. Jørstad declare that they have no competing interests.

Open Access This article is licensed under a Creative Commons Attribution 4.0 International License, which permits use, sharing, adaptation, distribution and reproduction in any medium or format, as long as you give appropriate credit to the original author(s) and the source, provide a link to the Creative Commons licence, and indicate if changes were made. The images or other third party material in this article are included in the article's Creative Commons licence, unless indicated otherwise in a credit line to the material. If material is not included in the article's Creative Commons licence and your intended use is not permitted by statutory regulation or exceeds the permitted use, you will need to obtain permission directly from the copyright holder. To view a copy of this licence, visit http://creativecommons.org/licenses/by/4.0/. 


\section{References}

1. Baggish AL, Battle RW, Beckerman JG, et al. Sports cardiology: core curriculum for providing cardiovascular care to competitive athletes and highly active people. J Am Coll Cardiol. 2017;70:1902-18.

2. Heidbuchel H, Papadakis M, Panhuyzen-Goedkoop N, et al. Position paper: proposal for a core curriculum for a European sports cardiology qualification. Eur J Prev Cardiol. 2013;20:889-903.

3. Drezner JA, O'Connor FG, Harmon KG, et al. AMSSM position statement on cardiovascular preparticipation screening in athletes: current evidence, knowledge gaps, recommendations and future directions. Br J Sports Med. 2017;51:153-67.

4. Pelliccia A, Solberg EE, Papadakis M, et al. Recommendations for participation in competitive and leisure time sport in athletes with cardiomyopathies, myocarditis, and pericarditis: position statement of theSportCardiologySection of the European Association of Preventive Cardiology (EAPC). Eur HeartJ. 2019;40:19-33.

5. Drezner JA, Ackerman MJ, Anderson J, et al. Electrocardiographic interpretation in athletes: the "Seattle Criteria.". Br JSports Med. 2013;47:122-4.
6. Borjesson M, Dellborg M, Niebauer J, et al. Recommendations for participation in leisure time or competitive sports in athletes-patients with coronary artery disease: a position statement from the Sports Cardiology Section of the European Association of Preventive Cardiology (EAPC). Eur Heart J. 2018;40:13-8.

7. Kemps H, Kränkel N, Dörr M, et al. Exercise training for patients with type 2 diabetes and cardiovascular disease: what to pursue and how to do it. A position paper of the European Association of Preventive Cardiology (EAPC). Eur JPrev Cardiol. 2019;26:709-27.

8. Budts W, Börjesson M, Chessa M, et al. Physical activity in adolescents and adults with congenital heart defects: individualized exercise prescription. Eur Heart J. 2013;34:3669-74.

9. Mont L, Pelliccia A, Sharma S, et al. Pre-participation cardiovascular evaluation for athletic participants to prevent sudden death: position paper from the EHRA and the EACPR, branches of the ESC. Endorsed by APHRS, HRS, and SOLAECE. Europace. 2017;19:139-63.

10. Mitchell JH, Haskell W, Snell P, Van Camp SP. Task force 8: classification of sports. J Am Coll Cardiol. 2005;45:1364-7. 